\title{
Use of starter cultures isolated from native microbiota of artisanal sausage in the production of Italian sausage
}

\author{
Osmar Roberto DALLA SANTA ${ }^{1 *}$, Renata Ernlund Freitas de MACEDO $^{2}$, Herta Stutz DALLA SANTA ${ }^{1}$, \\ Cristina Maria ZANETTE ${ }^{1}$, Renato João Sossela de FREITAS ${ }^{3}$, Nelcindo Nascimento TERRA ${ }^{4}$
}

\begin{abstract}
The most promising microorganisms for use as starter cultures are those isolated from the native microbiota of traditional fermented products. The aim of this study was to evaluate the use of lactic acid bacteria selected from the native microbiota of sausages produced by spontaneous fermentation as starter cultures for the production of sausage. Strains of Lactobacillus plantarum 503 and 341 have the potential for use as starter cultures in the manufacture of Italian sausage type. The population of lactic acid bacteria in sausages was $>8 \log \mathrm{CFU} . \mathrm{g}^{-1}$ during fermentation, which caused the $\mathrm{pH}$ to decrease to $<4.5$. This decrease in $\mathrm{pH}$ and the water activity of $<0.90$ of sausages ensures the safety and preservation of this product. Sausages produced with these lactic cultures fulfill the requirements for microbiological quality and composition of Italian sausage type. Our results suggest the possibility of using these starter cultures for the production of sausages with peculiar characteristics that contribute to the identity of the product.
\end{abstract}

Keywords: lactic acid bacteria; Lactobacillus; embedded fermented meat; sausage.

Practical Application: New autochthonous starter cultures contributes to the production of high quality sausage.

\section{Introduction}

For industrial meat production, it is important to increase the shelf life, develop different flavors, and use parts of difficultto-market carcass and sub-products such as the blood, stomach, liver and skin, which are easily marketable as a part of the formulation of meat products (Terra, 1998).

Fermentation is one of the oldest methods of processing and preserving foods (Hansen, 2002). Fermented sausages are characterized by their low moisture content and the resulting low water activity (AW) as well as the presence of lactic acid in an amount that imparts a distinctive and pleasant taste to the final product. The processing of these products by using combined methods of preservation imparts stability to the product when stored at the room temperature (Hugas \& Monfort, 1997; Leroy et al., 2013; Fanco et al., 2002).

In last decades, studies on the physiology and genetics of lactic acid bacteria (LAB) microbiota in meat products have emphasized the importance of these bacteria as starter cultures and as potential economical probiotic strains (Ammor \& Mayo, 2007; Ruiz-Moyano et al., 2008).

However, the biodiversity of commercial starter cultures is limited. Therefore, the selection and development of new starter cultures from the native microbiota of sausages produced by spontaneous fermentation as well as their use in the production of sausages can result in the development of products with high level of hygiene and regional products with specific sensory characteristics (Talon et al., 2007; Cocolin et al., 2011).

LAB have adapted to the ecological niche of fermented meats; this fact should be considered during the selection of starter cultures (Hugas \& Monfort, 1997; Landeta et al., 2013), because it shows that these bacteria are competitive with the native microbiota. In line with this, the aim of the present study was to evaluate the potential of autochthonous strains of Lactobacillus plantarum isolated from the microbiota of artisanal sausages for use as a starter culture in the production of Italian sausage type.

\section{Material and methods}

Strains of L. plantarum 503 (Lp503) and L. plantarum 341 (Lp341) used in this study were isolated from artisanal sausage, produced by spontaneous fermentation, and selected in a previous study based on their technological and probiotic characteristics (Dalla Santa, 2008).

To evaluate the effect of these $\mathrm{LAB}$ strains in the production of Italian sausages, the treatments described in Table 1 were performed by using the standard formulation of Italian sausage type as the reference. The standard formulation was as follows: $60 \%$ pork meat, $20 \%$ beef and $20 \%$ pork fat; with $(\mathrm{g} / \mathrm{kg}$ of meat mixture): salt -25 ; glucose -5 ; sucrose -5 ; sodium erythorbate 
Table 1. Treatments for testing the effect of Lactobacillus plantarum 503 (Lp503) and Lactobacillus plantarum 341 (Lp341) in the production of Italian sausage.

\begin{tabular}{cl}
\hline Treatment 1 & Standard formulation added of starter culture Floracarn SPX (Hansen Ind. e Com Ltda, Valinhos, Brazil) containing Pediococcus \\
(Control) & pentosaceus and Staphylococcus xylosus \\
Treatment 2 & Standard formulation added of starter cultures of Lactobacillus plantarum 503 (7 log CFU.g ${ }^{-1}$ of sausage) and the commercial culture \\
(Lp503) & Floracarn SX (Hansen Ind. e Com Ltda, Valinhos, Brazil) containing Staphylococcus xylosus \\
Treatment 3 & Standard formulation added of starter cultures of Lactobacillus plantarum 341 (7 log CFU.g of sausage) and the commercial culture \\
(Lp341) & Floracarn SX (Hansen Ind. e Com Ltda, Valinhos, Brazil) containing Staphylococcus xylosus \\
\hline
\end{tabular}

- 2.5; white pepper - 2.0; garlic - 3.0; nutmeg - 0.2 and; curing salts - 3.0 (Terra, 1998).

\subsection{Conditions in the ripening chamber during sausage production}

After embedding in the sausage casing with a diameter of 45-55 mm (Tripacon Ltda, Curitba, Brazil), salami pieces (approximately $25 \mathrm{~cm}$ in diameter) were identified and stored in the climate chamber (Menocin, Erechim, Brazil) according to the conditions described in Table 2. The samples were kept in the climate chamber until they achieved an AW of 0.87, which is the parameter for completing the production of Italian sausage type (Terra, 1998).

After ripening, the sausage pieces were vacuum packed (Selovac 200B, São Paulo, Brazil) and stored at room temperature $\left(22 \pm 3^{\circ} \mathrm{C}\right)$ for further characterization.

\subsection{Monitoring sausage production}

The sausages were analyzed at days $0,3,7$ and 14 . The following microorganisms were analyzed to evaluate the evolution of the microbiota as per the methods described by Silva et al. (2007): aerobic mesophilic bacteria (AMB), lactic acid bacteria (LAB), Staphylococcus spp., coagulase-positive Staphylococcus, fecal coliforms and total coliforms (TC).

The changes in the following physicochemical characteristics of sausages during the fermentation/maturation were determined as follows: (i) AW measured using the Aqualab CX2 (Decagon Devices Inc., Pullman, USA) (Ambrosiadis et al., 2004), (ii) pH measured using a digital potentiometer (Requipal RQ 210; Curitiba, Brazil) (Samelis et al, 1994), and (iii) weight loss estimated by a gravimetric method (Gehaka, São Paulo, Brazil) by measuring the difference between the initial weight and the final weight of the sausage pieces (Macedo et al., 2008).

\subsection{Physicochemical characterization of sausages}

After manufacturing, the physicochemical characterization of sausages was performed to verify the product conformance with the quality standards of Italian sausage (Brasil, 2000). Determinations of AW (Ambrosiadis et al., 2004) and contents of moisture, protein (AOAC, 2000) and fat (Bligh \& Dyer, 1959) were performed.

\subsection{Analysis of results}

The data obtained during sausage processing were submitted to the calculation of mean, standard deviation and variance analysis. Tukey's test was performed for comparison
Table 2. Climatic conditions in the chamber during sausage production.

\begin{tabular}{ccc}
\hline Time (days) & Temperature $\left({ }^{\circ} \mathrm{C}\right)$ & Relative humidity $(\%)$ \\
\hline 1 & 25 & 95 \\
2 & 24 & 93 \\
3 & 23 & 90 \\
4 & 22 & 85 \\
5 & 21 & 80 \\
6 & 20 & 75 \\
$7-14$ & 18 & 75 \\
\hline
\end{tabular}

Fonte: Terra (1998).

of the mean differences among samples $(\mathrm{p}<0.05)$. Statistical analysis was performed by using the GraphPad Prism 4.00.255 software (GraphPad Software, Inc.). The data represent the mean of triplicates.

\section{Results and discussion}

\subsection{Changes in the microbiota during sausage production}

The results of microbiological analyses of sausage during fermentation/maturation are presented in Table 3. The initial population (day 0) of AMB in the control group was lower than that in the treatment group; it was also lower than the initial population of LAB $(\mathrm{p}<0.05)$. This result reflects the higher counts of LAB in treatments 2 and 3 as compared to those in the control. In all treatment groups, the population of $\mathrm{AMB}$ increased during the processing of sausages, with $>8 \log \mathrm{CFU} \cdot \mathrm{g}^{-1}$ count on day 3 of fermentation, and remaining at that level until day 14 in the control and treatment 2.

Characterization studies of sausages produced from spontaneous fermentation from Greece, Italy and Spain, reported an AMB count in the final product of approximately $8 \log$ CFU.g ${ }^{-1}$ (Samelis et al., 1994; Mauriello et al., 2004; Moretti et al., 2004; Comi et al., 2005; Drosinos et al., 2005; Cenci-Goga et al., 2012).

In addition, the $\mathrm{LAB}$ count increased rapidly in all treatments, reaching the maximum value on day 3 (Table 2) and remaining at that value until the end of ripeness of sausage. These results corroborate with those described by Herranz et al. (2004), Cenci-Goga et al. (2008) and Zdolec et al. (2008).

The adaptation of the bacterial strains to the meat environment and the meat processing conditions may have mainly contributed to the fast multiplication of these microorganisms in the meat mixture. The rapid growth of LAB is important for the production of sausages, because it leads to sugar metabolization with consequent formation of organic 
Table 3. The mean values and standard deviation of the counts of aerobic mesophilic bacteria (AMB), lactic acid bacteria (LAB), coagulasenegative Staphylococcus (CNS) and total coliforms (TC) in the samples of Italian sausage $(\mathrm{n}=3)$.

\begin{tabular}{|c|c|c|c|c|}
\hline \multirow{2}{*}{ Analysis } & \multirow{2}{*}{ Time (day) } & \multicolumn{3}{|c|}{ Treatments } \\
\hline & & Control SPX & 2 - Lp503 & 3 - Lp314 \\
\hline \multirow[t]{4}{*}{ AMB (log UFC.g $\left.{ }^{-1}\right)$} & 0 & $4.88 \pm 0.35^{\mathrm{b}}$ & $7.03 \pm 0.46^{\mathrm{a}}$ & $5.88 \pm 0.15^{\mathrm{a}}$ \\
\hline & 3 & $8.53 \pm 0.07^{\mathrm{a}}$ & $8.63 \pm 0.08^{\mathrm{a}}$ & $8.06 \pm 0.06^{\mathrm{a}}$ \\
\hline & 7 & $8.92 \pm 0.06^{\mathrm{a}}$ & $8.68 \pm 0.14^{\mathrm{a}}$ & $7.75 \pm 0.10^{\mathrm{a}}$ \\
\hline & 14 & $8.98 \pm 0.12^{\mathrm{a}}$ & $8.12 \pm 0.28^{\mathrm{a}}$ & $7.55 \pm 0.27^{\mathrm{a}}$ \\
\hline \multirow[t]{4}{*}{ LAB (log UFC. $\left.g^{-1}\right)$} & 0 & $6.08 \pm 0.06^{\mathrm{b}}$ & $7.34 \pm 0.60^{\mathrm{a}}$ & $6.91 \pm 0.04^{\mathrm{a}}$ \\
\hline & 3 & $8.99 \pm 0.06^{\mathrm{a}}$ & $8.63 \pm 0.05^{\mathrm{b}}$ & $8.69 \pm 0.08^{\mathrm{ab}}$ \\
\hline & 7 & $8.73 \pm 0.06^{\mathrm{a}}$ & $8.92 \pm 0.26^{\mathrm{a}}$ & $8.55 \pm 0.10^{\mathrm{a}}$ \\
\hline & 14 & $9.01 \pm 0.05^{\mathrm{a}}$ & $8.12 \pm 0.22^{\mathrm{b}}$ & $8.65 \pm 0.12^{\mathrm{ab}}$ \\
\hline \multirow[t]{4}{*}{ CNS (log UFC.g $\left.{ }^{-1}\right)$} & 0 & $3.51 \pm 0.54^{\mathrm{b}}$ & $5.20 \pm 0.41^{\mathrm{a}}$ & $4.72 \pm 0.10^{\mathrm{a}}$ \\
\hline & 3 & $6.73 \pm 0.04^{\mathrm{a}}$ & $4.27 \pm 0.10^{c}$ & $5.59 \pm 0.38^{\mathrm{b}}$ \\
\hline & 7 & $7.11 \pm 0.06^{\mathrm{a}}$ & $2.33 \pm 1.56^{c}$ & $4.99 \pm 0.25^{\mathrm{b}}$ \\
\hline & 14 & $6.49 \pm 0.08^{\mathrm{a}}$ & $2.59 \pm 2.21^{\mathrm{b}}$ & $2.01 \pm 2.32^{\mathrm{b}}$ \\
\hline \multirow[t]{4}{*}{ TC (log UFC.g $\left.{ }^{-1}\right)$} & 0 & $3.36 \pm 0.04^{\mathrm{a}}$ & $2.97 \pm 0.45^{\mathrm{a}}$ & $2.44 \pm 0.20^{\mathrm{b}}$ \\
\hline & 3 & $1.33 \pm 1.04^{\mathrm{a}}$ & $<1.00$ & $<1.00$ \\
\hline & 7 & $<1.00$ & $<1.00$ & $<1.00$ \\
\hline & 14 & $<1.00$ & $<1.00$ & $<1.00$ \\
\hline
\end{tabular}

The values indicated with the same letter in the same line are not significantly different $(\mathrm{p}<0.05)$. Control SPX - Sausages prepared with the starter culture Floracarn SPX containing Pediococcus pentosaceus and Staphylococcus xylosus; Treatment 2 - Lp503 - Sausages prepared with the starter cultures Lp503 and S. xylosus; Treatment 3 - Lp314 - Sausages prepared with the starter cultures Lp341 and S. xylosus.

acids, mainly lactic acid, which decreases the $\mathrm{pH}$ of the sausage. The decrease of $\mathrm{pH}$ is essential in sausage processing, because it contributes to the development of characteristic flavor, color and aroma, as well as to the microbiological stability of the product (Hammes et al., 1990; Hugas \& Monfort, 1997).

In artisan sausages produced in various countries, prepared without starter cultures, $\mathrm{LAB}$ are the dominant microorganisms during the fermentation, usually exceeding $8 \log \mathrm{CFU} \cdot \mathrm{g}^{-1}$ in ripe sausage (Comi et al., 2005; Drosinos et al., 2005; Greco et al., 2005; Zhao et al., 2011; Rubio et al., 2014). However, some studies have reported lactic population of $<8 \log$ CFU.g ${ }^{-1}$ after achieving ripeness (Sanz et al., 1997; Ansorena et al., 2002; Dalla Santa et al., 2012). The lactic acid population of sausage slowly reduces during storage (Comi et al., 2005; Drosinos et al., 2005; Greco et al., 2005; Zhao et al., 2011; Rubio et al., 2014).

Lebert et al. (2007) reported an LAB count of 6.5 and 7.9 log CFU.g ${ }^{-1}$ in handmade fermented sausages obtained from two small food factories in France. Macedo et al. (2008) reported an LAB count of $>8 \log \mathrm{CFU}_{\text {. }}{ }^{-1}$ in sausages prepared with probiotic cultures after 150 days of storage under refrigeration.

Like the LAB population, the CNS population in the control group was lower than that in the treatment groups at day $0(\mathrm{p}<0.05)$. However, at day 3 of fermentation, the population increased to 3 $\log$ CFU.g ${ }^{-1}$ and remained stable at that value until ripeness was achieved on day 14; the final population of this bacterium was higher in the control group than in the treatment groups $(\mathrm{p}<0.05)$. In sausages prepared with the starter cultures Lp503 and Lp341, the CNS populations were similar at day 0 and day 14 ; however, the population was higher $(\mathrm{p}<0.05)$ on days 3 and 7 of fermentation with the starter culture Lp341. These results can be attributed to the lower $\mathrm{pH}$ in these sausage samples as compared to that in the controls (Table 4) as well as to the high population of L. plantarum strains used as the starter culture in treatments 2 and 3. The limited growth of Staphylococcus spp. could have been due to its low competitiveness against active growth of LAB (Sanz et al., 1997; Papamanoli et al., 2002; Mauriello et al., 2004; Drosinos et al., 2005).

The limited growth of CNS in sausages may affect the quality of the final products. These microorganisms are associated with color development and reduced lipid oxidation, as well as with the development of characteristic flavor of sausages caused by the action of lipases and proteases (Søndergaard \& Stahnke, 2002). However, the color of the sausages in treatments 2 and 3 was similar to that of the control (data not shown).

Even in sausages produced without using starter cultures, the amount of Micrococcaceae is variable. However, the population of these microorganisms in the final product is usually >4 log CFU.g ${ }^{-1}$ (Samelis et al., 1994; Coppola et al., 2000; Gardini et al., 2002; Comi et al., 2005). In addition, a Micrococcaceae population of $<4 \log$ CFU.g ${ }^{-1}$ has been reported (Papamanoli et al., 2002; Drosinos et al., 2005).

Lebert et al. (2007) studied the diversity of microorganisms in traditional fermented sausages produced by small industries in France and found that the initial amount of Staphylococcus was approximately $4.2 \mathrm{log} \mathrm{CFU} \cdot \mathrm{g}^{-1}$. The population of these microorganisms increased to 5.4 and $6.5 \mathrm{log}$ CFU.g ${ }^{-1}$ during and at the end of fermentation, respectively.

In this study, coagulase-positive Staphylococcus $\left(<10 \mathrm{CFU} \mathrm{g}^{-1}\right)$ were not detected in the sausage samples, which is in accordance with the standards established by the Brazilian legislation (Brasil, 2001).

The initial count of TC (Table 3) was higher in the control and in treatment 2 groups $(\mathrm{p}<0.05)$. During the fermentation period (until day 7), a decrease in the population of these 
Dalla Santa et al.

Table 4. Mean values and standard deviation of the evolution of $\mathrm{pH}$, aw and weight loss during the sausages production ( $\mathrm{n}=3$ ).

\begin{tabular}{|c|c|c|c|c|}
\hline & \multirow{2}{*}{ Time (days) } & \multicolumn{3}{|c|}{ Treatment } \\
\hline & & Control SPX & 2 - Lp503 & 3 - Lp314 \\
\hline \multirow[t]{3}{*}{$\mathrm{pH}$} & 0 & $5.80 \pm 0.00^{\mathrm{a}}$ & $5.80 \pm 0.00^{\mathrm{a}}$ & $5.77 \pm 0.06^{\mathrm{a}}$ \\
\hline & 3 & $4.37 \pm 0.04^{\mathrm{a}}$ & $4.16 \pm 0.01^{\mathrm{b}}$ & $4.33 \pm 0.01^{\mathrm{a}}$ \\
\hline & 14 & $4.54 \pm 0.01^{\mathrm{a}}$ & $4.31 \pm 0.01^{c}$ & $4.40 \pm 0.02^{\mathrm{b}}$ \\
\hline \multirow[t]{2}{*}{ aw } & 0 & $0.98 \pm 0.00^{\mathrm{b}}$ & $0.98 \pm 0.00^{\mathrm{b}}$ & $0.99 \pm 0.00^{\mathrm{a}}$ \\
\hline & 14 & $0.87 \pm 0.01^{\mathrm{b}}$ & $0.87 \pm 0.00^{\mathrm{b}}$ & $0.89 \pm 0.00^{\mathrm{a}}$ \\
\hline \multirow[t]{4}{*}{ Weight loss (\%) } & 0 & - & - & - \\
\hline & 3 & $11.28 \pm 1.27^{\mathrm{a}}$ & $12.14 \pm 2.31^{\mathrm{a}}$ & $10.02 \pm 1.20^{\mathrm{a}}$ \\
\hline & 7 & $27.97 \pm 1.07^{\mathrm{a}}$ & $29.92 \pm 8.14^{\mathrm{a}}$ & $27.02 \pm 0.98^{\mathrm{a}}$ \\
\hline & 14 & $37.59 \pm 0.66^{\mathrm{a}}$ & $40.41 \pm 0.78^{\mathrm{a}}$ & $37.55 \pm 0.52^{\mathrm{a}}$ \\
\hline
\end{tabular}

The values indicated with the same letter in the same line are not significantly different $(\mathrm{p}<0.05)$. Control SPX - Sausages prepared with the starter culture Floracarn SPX containing Pediococcus pentosaceus and Staphylococcus xylosus; Treatment 2 - Lp503 - Sausages prepared with the starter cultures Lp503 and S. xylosus; Treatment 3 - Lp314 - Sausages prepared with the starter cultures Lp341 and S. xylosus.

microorganisms to values $<1.00 \mathrm{log} \mathrm{CFU}_{\mathrm{g}}{ }^{-1}$ was noted. The progressive reduction in the population of TC during fermentation confirmed the competitive superiority of LAB over the endogenous microbiota as well as that coliform bacteria do not grow well at low $\mathrm{pH}$. This phenomenon occurs in sausages prepared with the addition of starter cultures and in those produced by spontaneous fermentation (Sanz et al., 1997; González-Fernández et al., 2003; Drosinos et al., 2005; Cenci-Goga et al., 2012).

In fermented sausages produced by nine small industries in France, the population of Enterobacteriaceae was approximately $4.0 \log$ CFU.g ${ }^{-1}$; this count increased slightly during fermentation and then remained constant at approximately $4.3 \log \mathrm{CFU} . \mathrm{g}^{-1}$. After achieving ripeness, the population of these microorganisms decreased to approximately $2.3 \log$ CFU.g ${ }^{-1}$ (Lebert et al., 2007).

The main representative of fecal coliforms is Escherichia coli, which primarily inhabits the intestinal tract of humans and animals, and its detection in a sample indicates fecal contamination (Franco \& Landgraf, 2007). In sausages produced in this study, the presence of fecal coliforms $\left(<10\right.$ CFU.g $\left.{ }^{-1}\right)$ was not observed, which confirms the significance of using raw materials of appropriate quality and of sanitary processing conditions. Thus, the sausages produced in this study were in accordance with the standards established by the Brazilian legislation (Brasil, 2001).

\subsection{Physicochemical changes during processing of sausage}

The initial $\mathrm{pH}$ value of sausages was similar in all treatments (Table 4). After 3 days of fermentation, the $\mathrm{pH}$ of sausages of all treatments reached values below 4.4 , whereas treatment 2 differ from control. From the 7th day until the end of processing, the treatments added with strains of $L$. plantarum showed $\mathrm{pH}$ values lower than control, reaching values below 4.5 after ripeness. Reducing the $\mathrm{pH}$ of sausages depends on the type of starter culture used. L. plantarum strains tested showed higher fermentative activity in sausages compared to commercial lactic strain (P. pentosaceus), was observed most acidifying capacity for Lp503 strain. Differences in the ability of salamis acidification with the use of different starter cultures have also been observed in other studies (Erkkilä et al., 2001; González-Fernández et al., 2003; Komprda et al., 2004; Bedia et al., 2011).

Corroborating the results of other authors (Samelis et al., 1994; Gardini et al., 2002; Greco et al., 2005; Campagnol et al., 2007) was a slight increase in $\mathrm{pH}$ of the sausages of all treatments in maturation stage, after the 7 th day of processing. Fact attributed to the increased proteolytic activity, with the formation of peptides, amino acids and non-protein nitrogen compounds (Sanz et al., 1997; Fanco et al., 2002; Herranz et al., 2004; Durá et al., 2004).

In general, the final $\mathrm{pH}$ of the fermented sausages in several countries is highly variable, with an average value of approximately 5.0 (Samelis et al., 1994; Lorenzo et al., 2000; Ansorena et al., 2002; Fanco et al., 2002; Comi et al., 2005; Drosinos et al., 2005; Greco et al., 2005; Dalla Santa et al., 2006; Lebert et al., 2007; Holko et al., 2013). In this study, the final pH value of the sausages for all the treatments was approximately 4.5 , which is less than the average value reported in the literature.

According to the established quality standards for sausages (Brasil, 2000), the maximum acceptable value of AW for Italian sausage type is 0.90 . Therefore, the processing of sausages can only be stopped when the AW of the product reaches the value of 0.90 .

During the first 3 days of processing of the sausages, a small reduction in the aw was noted, which reflected the conditions of relative humidity $>90 \%$ in the climate chamber. Relative humidity is one of the factors that affect the rate of dehydration of sausages. In addition, during the maturation of sausages (from 7 to 14 days of fermentation), the humidity of the chamber was reduced to $75 \%$ in order to facilitate the process of dehydration and, consequently, for the reduction of the AW of sausages, which reached to values $<0.90$ in all treatments at the end of the ripeness stage. 
Table 5. Physicochemical characteristics of sausages after ripening $(\mathrm{n}=3)$.

\begin{tabular}{lccc}
\hline & \multicolumn{3}{c}{ Treatments } \\
\cline { 2 - 4 } & Control SPX & $2-$ Lp503 & $3-$ Lp341 \\
\hline AW & $0.87 \pm 0.01^{\mathrm{b}}$ & $0.87 \pm 0.01^{\mathrm{b}}$ & $0.89 \pm 0.01^{\mathrm{a}}$ \\
Humidity (\%) & $27.68 \pm 0.13^{\mathrm{b}}$ & $26.70 \pm 0.27^{\mathrm{c}}$ & $32.33 \pm 0.14^{\mathrm{a}}$ \\
Protein (\%) & $28.27 \pm 0.15^{\mathrm{a}}$ & $28.79 \pm 0.33^{\mathrm{a}}$ & $27.02 \pm 0.21^{\mathrm{b}}$ \\
Fat (\%) & $34.83 \pm 0.67^{\mathrm{a}}$ & $34.59 \pm 1.13^{\mathrm{a}}$ & $31.68 \pm 0.47^{\mathrm{a}}$ \\
\hline
\end{tabular}

The values indicated with the same letter in the same line are not significantly different $(\mathrm{p}<0.05)$. Control SPX - Sausages prepared with the starter culture Floracarn SPX containing Pediococcus pentosaceus and Staphylococcus xylosus; Treatment 2 - Lp503 Sausages prepared with the starter cultures Lp503 and S. xylosus; Treatment 3 - Lp314 - Sausages prepared with the starter cultures Lp341 and S. xylosus.

The reduction in the AW of sausages is also associated with the decrease in $\mathrm{pH}$. When the $\mathrm{pH}$ approaches the isoelectric point of the myofibrillar proteins of meat (5.3-5.5), the waterretention capability also decreases, facilitating dehydration and, consequently, reducing the AW of sausages (Mauriello et al., 2004).

Considering the loss of weight of sausages, there was no significant difference between treatments $(\mathrm{p}<0.05)$ at all time periods of evaluation, although treatment 2 samples showed lower $\mathrm{pH}$ values, which influenced the loss of weight of products.

The loss of weight of sausages in this study (37.55-40.41\%) was similar to that reported by Campos (2002), who observed loss of weight at the end of processing of Italian sausage type at 37.9-40.7\%. Macedo et al. (2008) reported values of weight loss at $30.46-38.18 \%$ in sausages prepared with probiotic cultures.

Reduction in the water content of sausages during the maturation period is a major factor that contributes to the texture of the final product (Fernández et al., 2000). During this period, the development of flavor of sausages also occurs as a result of chemical and biochemical reactions that involve proteins, fats and carbohydrates (Hansen, 2002). Moreover, the reduction in the AW of maturing sausages limits the development of spoilage-causing and pathogenic bacteria, which increases the stability and security of the final food product (Hugas \& Monfort, 1997).

\subsection{Physicochemical characteristics of sausages after processing}

The water content of sausages differed significantly $(\mathrm{p}<0.05)$ among the treatments (Table 5). Treatment 3 sample showed higher moisture content and higher AW compared to other samples. However, these values were in accordance to the standard requirements of the technical regulation of identity and quality of Italian sausage type (Brasil, 2000), which specifies a maximum AW of 0.90 value and $35 \%$ moisture content. The values in this study were generally lower than those reported in other studies. Macedo et al. (2008) obtained moisture content of 36.55-42.54\% for sausages produced with probiotic cultures. Similar results were reported for sausages produced by Campos (2002), with the moisture content ranging from $38.7 \%$ to $43.6 \%$. In a study to characterize the typical sausage of Spain (Androlla), Lorenzo et al. (2000) reported a moisture content of 28.9-55.1\%.
Difference in the protein content was observed among treatments $(p<0.05)$, but the values were similar $(27.02-28.79 \%)$ and more than the minimum content of protein $(25 \%)$ established by the Brazilian legislation for Italian sausage type (Brasil, 2000).

The fat content of sausages did not show a significant difference between the control and treatment groups $(\mathrm{p}<0.05)$; however, the control and treatment 2 groups had slightly more fat content (up to 32\%) than the standard limit (Brasil, 2000).

\section{Conclusions}

Strains Lp503 and Lp341 are potential candidates for use as starter cultures in the production of Italian sausage type. The population of LAB in sausages was $>8 \log \mathrm{CFU} \cdot \mathrm{g}^{-1}$ during fermentation, which led to a decrease in the $\mathrm{pH}$ value to $<4.5$. The acidification and the AW value of $<0.90$ ensures the safety and preservation of sausages during storage. Sausages produced with Lp503 and Lp341 starter cultures are in accordance with the requirements for microbiological quality and chemical composition for Italian sausage type with the established standards. Our results suggest the possibility of using these starter cultures for the production of sausages to impart peculiar characteristics to the final product, giving it a unique identity.

\section{References}

Ambrosiadis, J., Soultos, N., Abrahim, A., \& Bloukas, J. G. (2004). Physicochemical, microbiological and sensory attributes for the characterization of Greek traditional sausages. Meat Science, 66(2), 279-287. http://dx.doi.org/10.1016/S0309-1740(03)00100-1. PMid:22064129

Ammor, M. S., \& Mayo, B. (2007). Selection criteria for lactic acid bacteria to be used as functional starter cultures in dry sausage production: An update. Meat Science, 76(1), 138-146. http://dx.doi. org/10.1016/j.meatsci.2006.10.022. PMid:22064200

Ansorena, D., Montel, M. C., Rokka, M., Talon, R., Eerola, S., Rizzo, A., Raemaekers, M., \& Demeyer, D. (2002). Analysis of biogenic amines in northern and southern European sausages and role of flora in amine production. Meat Science, 61(2), 141-147. http:// dx.doi.org/10.1016/S0309-1740(01)00174-7. PMid:22064002

Association of Official Analytical Chemists - AOAC. (2000). Official methods of analysis of AOAC International (17th ed). Washington: AOAC.

Bedia, M., Méndez, L., \& Bañón, S. (2011). Evaluation of different starter cultures (Staphylococci plus Lactic Acid Bacteria) in semiripened Salami stuffed in swine gut. Meat Science, 87(4), 381-386. http://dx.doi.org/10.1016/j.meatsci.2010.11.015. PMid:21177044

Bligh, E. G., \& Dyer, W. J. (1959). A rapid method of total lipid extraction and purification. Canadian Journal of Biochemistry and Physiology, 37(8), 911-917. http://dx.doi.org/10.1139/o59-099. PMid:13671378

Brasil, Ministério da Agricultura e do Abastecimento. (2000). Anexo V: Regulamento Técnico de identidade e qualidade de salame (Instrução Normativa no 22, de 31 de junho de 2000). Diário Oficial da República Federativa do Brasil. Retrieved from http://www. engetecno.com.br/legislacao/carnes_salame.htm.

Brasil, Ministério da Saúde, Agência Nacional de Vigilância Sanitária - ANVISA. (2001). Aprova o Regulamento Técnico sobre padrões microbiológicos para alimentos (Resolução RDC $n^{\circ} 12$, de 2 de 
janeiro de 2001). Diário Oficial da República Federativa do Brasil. Retrieved from http://portal.anvisa.gov.br/wps/wcm/ connect/a47bab8047458b909541d53fbc4c6735/RDC_12_2001. pdf?MOD=AJPERES.

Campagnol, P. C. B., Fries, L. L. M., Terra, N. N., Santos, B. A., \& Furtado, A. S. (2007). Salame elaborado com Lactobacillus plantarum fermentado em meio de cultura de plasma suíno. Ciência e Tecnologia de Alimentos, 27(4), 833-889. http://dx.doi.org/10.1590/ S0101-20612007000400032.

Campos, R. M. L. (2002). Influência da alimentação na qualidade da carcaça suína e do pernil para a fabricação de salame tipo italiano (Dissertação de mestrado). Universidade Federal de Santa Maria, Santa Maria.

Cenci-Goga, B. T., Ranucci, D., Miraglia, D., \& Cioffi, A. (2008). Use of starter cultures of dairy origin in the production of Salame nostrano, an Italian dry-cured sausage. Meat Science, 78(4), 381-390. http:// dx.doi.org/10.1016/j.meatsci.2007.07.001. PMid:22062456

Cenci-Goga, B. T., Rossitto, P. V., Sechi, P., Parmegiani, S., Cambiotti, V., \& Cullor, J. S. (2012). Effect of selected dairy starter cultures on microbiological, chemical and sensory characteristics of swine and venison (Dama dama) nitrite-free dry-cured sausages. Meat Science, 90(3), 599-606. http://dx.doi.org/10.1016/j.meatsci.2011.09.022. PMid:22032919

Cocolin, L., Dolci, P., \& Rantsiou, K. (2011). Biodiversity and dynamics of meat fermentations: the contribution of molecular methods for a better comprehension of a complex ecosystem. Meat Science, 89(3), 296-302. http://dx.doi.org/10.1016/j.meatsci.2011.04.011. PMid:21555189

Comi, G., Urso, R., Iacumin, L., Rantsiou, K., Cattaneo, P., Cantoni, C., \& Cocolin, L. (2005). Characterisation of naturally fermented sausages produced in the North East of Italy. Meat Science, 69(3), 381-392. http://dx.doi.org/10.1016/j.meatsci.2004.08.007. PMid:22062975

Coppola, S., Mauriello, G., Aponte, M., Moschetti, G., \& Villani, F. (2000). Microbial succession during ripening of Naples-type salami, a southern Italian fermented sausage. Meat Science, 56(4), 321-329. http://dx.doi.org/10.1016/S0309-1740(00)00046-2. PMid:22062161

Dalla Santa, O. R. (2008). Avaliação da qualidade de salames artesanais e seleção de culturas starter para a produção de salame tipo italiano (Tese de doutorado). Universidade Federal do Paraná, Curitiba.

Dalla Santa, O. R., Chacón Alvarez, D., Dalla Santa, H. S., Zanette, C. M., Freitas, R. J. S., Macedo, R. E. F., \& Terra, N. N. (2012). Microbiota of sausages obtained by spontaneous fermentation produced in the South of Brazil. Ciência e Tecnologia de Alimentos, 32(4), 653-660. http://dx.doi.org/10.1590/S0101-20612012005000117.

Dalla Santa, O. R., Coelho, F. A., Freitas, J. R. S., Dalla Santa, H. S., \& Terra, N. N. (2006). Características de salamis fermentados producidos sin adición de cultivo iniciador. Ciencia y Tecnologia Alimentaria, 5(3), 231-236. http://dx.doi.org/10.1080/11358120609487696.

Drosinos, E. H., Mataragas, M., Xiraphi, N., Moschonas, G., Gaitis, F., \& Metaxopoulos, J. (2005). Characterization of the microbial flora from a traditional Greek fermented sausage. Meat Science, 69(2), 307-317. http://dx.doi.org/10.1016/j.meatsci.2004.07.012. PMid:22062823

Durá, M. A., Flores, M., \& Toldrá, F. (2004). Effect of Debaryomyces spp. on the proteolysis of dry-fermented sausages. Meat Science, 68(2), 319-328. http://dx.doi.org/10.1016/j.meatsci.2004.03.015. PMid:22062243

Erkkilä, S., Petäjä, E., Eerola, S., Lilleberg, L., Mattila-Sandholm, T., \& Suihko, M.-L. (2001). Flavour profiles of dry sausages fermented by selected novel meat starter cultures. Meat Science, 58(2), 111-116. http://dx.doi.org/10.1016/S0309-1740(00)00135-2. PMid:22062105

Fanco, I., Prieto, B., Cruz, J. M., López, M., \& Carballo, J. (2002). Study of the biochemical changes during the processing of Androlla, a Spanish dry-cured pork sausage. Food Chemistry, 78(3), 339-345. http://dx.doi.org/10.1016/S0308-8146(02)00118-8.

Fernández, M., Ordóñez, J. A., Bruna, J. M., Herranz, B., \& de la Hoz, L. (2000). Accelerated ripening of dry fermented sausages. Trends in Food Science \& Technology, 11(6), 201-209. http://dx.doi. org/10.1016/S0924-2244(00)00077-7.

Franco, B. D. G. M., \& Landgraf, M. (2007). Microbiologia dos alimentos. São Paulo: Atheneu.

Gardini, F., Martuscelli, M., Crudele, M. A., Paparella, A., \& Suzzi, G. (2002). Use of Staphylococcus xylosus as a starter culture in dried sausages: effect on the biogenic amine content. Meat Science, 61(3), 275-283. http://dx.doi.org/10.1016/S0309-1740(01)00193-0. PMid:22060850

González-Fernández, C., Santos, E. M., Jaime, I., \& Rovira, J. (2003). Influence of starter culture and sugar concentration on biogenic amine contents in chorizo dry sausage. Food Microbiology, 20(3), 275-284. http://dx.doi.org/10.1016/S0740-0020(02)00157-0.

Greco, M., Mazzette, R., De Santis, E. P. L., Corona, A., \& Cosseddu, A. M. (2005). Evolution and identification of lactic acid bacteria isolated during the ripening of Sardinian sausages. Meat Science, 69(4), 733-739. http://dx.doi.org/10.1016/j.meatsci.2004.11.004. PMid:22063151

Hammes, W., Bantleon, A., \& Min, S. (1990). Lactic acid bacteria in meat fermentation. FEMS Microbiology Reviews, 87(1-2), 165-174. http://dx.doi.org/10.1111/j.1574-6968.1990.tb04886.x.

Hansen, E. B. (2002). Commercial bacterial starter cultures for fermented foods of the future. International Journal of Food Microbiology, 78(1-2), 119-131. http://dx.doi.org/10.1016/S01681605(02)00238-6. PMid:12222629

Herranz, B., Fernández, M., Hierro, E., Bruna, J. M., Ordóñez, J. A., \& de la Hoz, L. (2004). Use of Lactococcus lactis subsp. cremoris NCDO 763 and a-ketoglutarate to improve the sensory quality of dry fermented sausages. Meat Science, 66(1), 151-163. http://dx.doi. org/10.1016/S0309-1740(03)00079-2. PMid:22063943

Holko, I., Hrabě, J., Šalaková, A., \& Rada, V. (2013). The substitution of a traditional starter culture in mutton fermented sausages by Lactobacillus acidophilus and Bifidobacterium animalis. Meat Science, 94(3), 275-279. http://dx.doi.org/10.1016/j. meatsci.2013.03.005. PMid:23567124

Hugas, M., \& Monfort, J. M. (1997). Bacterial starter cultures for meat fermentation. Food Chemistry, 59(4), 547-554. http://dx.doi. org/10.1016/S0308-8146(97)00005-8.

Komprda, T., Smělá, D., Pechová, P., Kalhotka, L., Stencl, J., \& Klejdus, B. (2004). Effect of starter culture, spice mix and storage time and temperature on biogenic amine content of dry fermented sausages. Meat Science, 67(4), 607-616. http://dx.doi.org/10.1016/j. meatsci.2004.01.003. PMid:22061810

Landeta, G., Curiel, J. A., Carrascosa, A. V., Muñoz, R., \& de las Rivas, B. (2013). Technological and safety properties of lactic acid bacteria isolated from Spanish dry-cured sausages. Meat Science, 95(2), 272280. PMid:23743032.

Lebert, I., Leroy, S., Giammarinaro, P., Lebert, A., Chacornac, J. P., Bover-Cid, S., Vidal-Carou, M. C., \& Talon, R. (2007). Diversity of microorganisms in the environment and dry fermented sausages of small traditional French processing units. Meat Science, 
76(1), 112-122. http://dx.doi.org/10.1016/j.meatsci.2006.10.019. PMid:22064197

Leroy, F., Geyzen, A., Janssens, M., De Vuyst, L., \& Scholliers, P. (2013). Meat fermentation at the crossroads of innovation and tradition: A historical outlook. Trends in Food Science \& Technology, 31(2), 130-137. http://dx.doi.org/10.1016/j.tifs.2013.03.008.

Lorenzo, J. M., Michinel, M., López, M., \& Carballo, J. (2000). Biochemical Characteristics of Two Spanish Traditional Drycured Sausage Varieties: Androlla and Botillo. Journal of Food Composition and Analysis, 13(5), 809-817. http://dx.doi. org/10.1006/jfca.2000.0927.

Macedo, R. E. F., Pflanzer, S. B. Jr, Terra, N. N., \& Freitas, R. J. S. (2008). Desenvolvimento de um embutido fermentado por Lactobacillus probióticos: características de qualidade. Ciência e Tecnologia de Alimentos, 28(3), 509-519. http://dx.doi.org/10.1590/S010120612008000300002.

Mauriello, G., Casaburi, A., Blaiotta, G., \& Villani, F. (2004). Isolation and technological properties of coagulase negative staphylococci from fermented sausages of Southern Italy. Meat Science, 67(1), 149-158. http://dx.doi.org/10.1016/j.meatsci.2003.10.003. PMid:22061128

Moretti, V. M., Madonia, G., Diaferia, C., Mentasti, T., Paleari, M. A., Panseri, S., Pirone, G., \& Gandini, G. (2004). Chemical and microbiological parameters and sensory attributes of a typical Sicilian salami ripened in different conditions. Meat Science, 66(4), 845-854. http://dx.doi.org/10.1016/j.meatsci.2003.08.006. PMid:22061017

Papamanoli, E., Kotzekidou, P., Tzanetakis, N., \& Litopoulou-Tzanetaki, E. (2002). Characterization of Micrococcaceae isolated from dry fermented sausage. Food Microbiology, 19(5), 441-449. http://dx.doi. org/10.1006/fmic.2002.0503.

Rubio, R., Jofré, A., Aymerich, T., Guàrdia, M. D., \& Garriga, M. (2014). Nutritionally enhanced fermented sausages as a vehicle for potential probiotic lactobacilli delivery. Meat Science, 96(2 Pt A), 937-942. http://dx.doi.org/10.1016/j.meatsci.2013.09.008. PMid:24211552

Ruiz-Moyano, S., Martín, A., Benito, M. J., Nevado, F. P., \& de Guía Córdoba, M. (2008). Screening of lactic acid bacteria and bifidobacteria for potential probiotic use in Iberian dry fermented sausages. Meat Science, 80(3), 715-721. http://dx.doi.org/10.1016/j. meatsci.2008.03.011. PMid:22063588

Samelis, J., Stavropoulos, S., Kakouri, A., \& Metaxopoulos, J. (1994). Quantification and characterization of microbial populations associated with naturally fermented Greek dry salami. Food Microbiology, 11(6), 447-460. http://dx.doi.org/10.1006/ fmic.1994.1050.

Sanz, Y., Flores, J., Toldra, F., \& Feria, A. (1997). Effect of pre-ripening on microbial and chemical changes in dry fermented sausages. Food Microbiology, 14(6), 575-582. http://dx.doi.org/10.1006/ fmic.1997.0121.

Silva, N., Junqueira, V. C. A., Silveira, N. F. A., Taniwaki, M. H., Santos, R. F. S., \& Gomes, R. A. R. (2007). Manual de métodos de análise microbiológica de alimentos e água. São Paulo: Varela.

Søndergaard, A. K., \& Stahnke, L. H. (2002). Growth and aroma production by Staphylococcus xylosus, S. carnosus and S. equorum-a comparative study in model systems. International Journal of Food Microbiology, 75(1-2), 99-109. http://dx.doi. org/10.1016/S0168-1605(01)00729-2. PMid:11999121

Talon, R., Leroy, S., \& Lebert, I. (2007). Microbial ecosystems of traditional fermented meat products: The importance of indigenous starters. Meat Science, 77(1), 55-62. http://dx.doi.org/10.1016/j. meatsci.2007.04.023. PMid:22061396

Terra, N. N. (1998). Apontamentos de tecnologia de carnes. São Leopoldo: Unissinos.

Zdolec, N., Hadžiosmanović, M., Kozačinski, L., Cvrtila, Z., Filipović, I., Skrivanko, M., \& Leskovar, K. (2008). Microbial and physicochemical succession in fermented sausages produced with bacteriocinogenic culture of Lactobacillus sakei and semi-purified bacteriocin mesenterocin Y. Meat Science, 80(2), 480-487. http:// dx.doi.org/10.1016/j.meatsci.2008.01.012. PMid:22063356

Zhao, L., Jin, Y., Ma, C., Song, H., Li, H., Wang, Z., \& Xiao, S. (2011). Physico-chemical characteristics and free fatty acid composition of dry fermented mutton sausages as affected by the use of various combinations of starter cultures and spices. Meat Science, 88(4), 761-766. http://dx.doi.org/10.1016/j.meatsci.2011.03.010. PMid:21458169 


\section{Erratum}

Article:

"Use of starter cultures isolated from native microbiota of artisanal sausage in the production of Italian sausage."

Published in Volume 34, Issue 4 of this Journal

Author's affiliation:

Renata Ernlund Freitas Macedo - Pontifícia Universidade Católica do Paraná - PUCPR, Curitiba, PR, Brasil

Herta Stutz Dalla Santa e Cristina Maria Zanette: - Universidade Estadual do Centro-Oeste - UNICENTRO, Guarapuava, PR, Brasil 